\title{
INFLUENCE OF THE SEALER AND A PLUG IN CORONAL LEAKAGE AFTER POST SPACE PREPARATION
}

\author{
INFLUÊNCIA DO CIMENTO OBTURADOR E DE UM "PLUG" \\ NA INFILTRAÇÃO CORONÁRIA APÓS PREPARO PARA PINO
}

\author{
Roberto HOLLAND ${ }^{1}$, Sueli Satomi MURATA², Monica Nunes da SILVA ${ }^{3}$, Eloi DEZAN JUNIOR ${ }^{4}$, \\ Valdir de SOUZA ${ }^{1}$, Pedro Felício Estrada BERNABÉ ${ }^{4}$
}

\author{
1- DDS, Associate Professor of Endodontics. Araçatuba Dental School-UNESP and post graduation course in Endodontics -UNIMAR - Marília, SP. \\ 2- DDS, MSc, PhD Graduate student in Pediatric Dentistry, Araçatuba Dental School - UNESP. SP. \\ 3- DDS, Endodontist in private practice, Brasília, Brazil. \\ 4- DDS, Associate Professor of Endodontics. Araçatuba Dental School - UNESP.. \\ Corresponding address: Dr. Roberto Holland - R. José Bonifácio 1193 CEP 16015-050 - Araçatuba-SP - E-mail: rholland@foa.unesp.br \\ Received: March 03, 2004 - Returned for modification: April 30, 2004 - Accepted: June 08, 2004
}

\begin{abstract}
$T_{\mathrm{h}}$

I he subject of this paper was to conduct an in vitro study of the coronal leakage after root canal filling and post space preparation. One hundred single-rooted human teeth had their crowns removed and the canals prepared and filled by the lateral condensation technique with gutta-percha points and the sealers CRCS and Endofill (a Grossman cement). After post space preparation, the remainder of the filling was protected or not with $1 \mathrm{~mm}$ of a plug of the following materials: Coltosol, Super Bonder (cyanoacrylate-ester), CRCS and Endofill. After 24 hours in saline, the specimens were immersed in a 2\% methylene blue solution in a vacuum environment for 24 hours. The teeth were then sectioned longitudinally, leakage was evaluated linearly and the obtained data were submitted to the Kruskal-Wallis test. The results with the two sealers studied were similar between themselves and worse $(\mathrm{p}<0.01)$ than the groups with a protector plug. The statistical analysis ordered the experimental groups from the best to the worst in the following way: a - Endofill-Super Bonder, CRCS-Super Bonder, CRCS-CRCS; b Endofill-Endofill; c - Endofill-Coltosol, CRCS-Coltosol; d - Endofill, CRCS.

Uniterms: Coronary leakage; Endofill; CRCS; Plug; Post space preparation.
\end{abstract}

\section{RESUMO}

objetivo deste trabalho foi avaliar "in vitro” a infiltração marginal coronária após obturação de canal e preparo para pino, empregando-se ou não um "plug” protetor. Cem dentes humanos unirradiculares extraídos tiveram suas coroas removidas, e os canais preparados biomecanicamente e obturados pela técnica da condensação lateral com cones de guta-percha e os cimentos CRCS e Endofill. Após preparo para pino, os remanescentes das obturações foram ou não protegidos por 1 mm de um "plug” dos seguintes materiais: Coltosol, Super Bonder, CRCS e Endofill. Após permanecerem 24 horas em soro fisiológico, os espécimes foram imersos em solução de azul de metileno a 2\%, em ambiente com vácuo, por 24 horas. Os dentes foram então seccionados longitudinalmente, as infiltrações marginais mensuradas linearmente, e os dados obtidos submetidos à análise de variância e teste de Kruskal-Wallis. Os resultados com os 2 cimentos estudados foram semelhantes entre si e piores ( $\tilde{n}<0,01$ ) do que os grupos com "plugs" protetores. A análise estatística ordenou os grupos experimentais do melhor para o pior da seguinte maneira: a- Endofill-Super Bonder, CRCS-Super Bonder, CRCS-CRCS; b- Endofill-Endofill; c- Endofill-Coltosol, CRCSColtosol; d- Endofill, CRCS.

Unitermos: Infiltração coronária; Endofill; CRCS; Plug; Preparo para pino.

\section{INTRODUCTION}

The sealing property of root canal fillings is a factor that can influence the result after root canal treatment ${ }^{13}$. Numerous investigations studied the root canal filling materials, techniques of filling and variables introduced in the filling techniques, in order to discover what procedures improve their sealing property $y^{4,5,7,8,9,14}$. 
An efficient apical filling can hinder the communication between the root canal and periapical tissues. However, some time ago the coronal sealing efficiency and the consequences of microorganism leakage across this route was questioned ${ }^{15}$.

Several in vitro experiments demonstrated that some microorganisms can penetrate the coronal portion of the root canal fillings in depth, reaching the apical region in variable numbers of cases and time ${ }^{16,18}$.

These observations motivated the development of some in vivo investigations, whose object was to observe if these in vitro occurrences could be detected in vivo. Thus, some experiments done in dog's teeth showed that root canal fillings exposed to the oral environment became vulnerable to microorganism leakage. Beside this, it was observed that the kind of sealer can influence the number of these occurrences ${ }^{6}$.

Considering these findings, one can admit that in cases of post space preparation, the amount of remainder filling material is minor, and the problem of coronal leakage can be major $^{1,12}$. Studying this subject, Barbosa, et al. ${ }^{2}$ developed an in investigation vivo in dog's teeth. The root canals were filled by the lateral condensation technique with guttapercha points and the sealers Roth or Sealer 26. After post space preparation the remainder of the filling was protected or not by a 1-millimeter plug of the temporary cement Lumicon. The root canal remained exposed to the oral environment for 90 days. The histological results showed that the incidence of microorganism leakage was higher with the cement Roth than with Sealer 26, and that the Lumicon plug hinders or decreases leakage.

The reported investigation showed that the kind of root canal sealer and the employment of a plug can influence the amount of coronal leakage. Considering that there are several kinds of root canal filling materials and cements that can be employed as a protector plug, one can admit the necessity of developing new research regarding this subject.

In view of the reported investigations, the subject of this paper was to analyze, in vitro, the influence of some different plugs on the protection of the remainder of root canal filling with two different sealers, after post space preparation.

\section{MATERIALAND METHODS}

One hundred single-rooted human teeth recently extracted were employed in this research. The crowns were removed and the canals prepared employing Gates-Glidden drill, crown-down preparation with Kerr files up to \# 40 until the CDJ limit, and step-back instrumentation with Hedstroen files up to file $\# 80^{10}$. The apical root canal was enlarged with \# 1/2 bur and filled with the temporary cement Coltosol (Vigodent, Rio de Janeiro, Brazil). The canals were frequently and thoroughly irrigated with $2 \%$ sodium hypochlorite during instrumentation. The external surface of the teeth was then coated with Araldite (Brascola Ltda-Brazil), except for the coronal access to root canal. The canals were then filled by the lateral condensation technique with guttapercha points and the sealers CRCS (Hygienic, Rio de Janeiro, Brazil) and Endofill (Dentsply, Petrópolis, Brazil), a Grossman cement.

Immediately after filling, a post space preparation was done with Gates-Glidden burs and heated pluggers, leaving a remainder of the filling of $5 \mathrm{~mm}$. The remainder of the filling material was then protected or not with a plug of $1 \mathrm{~mm}$ in thickness of Coltosol, Super Bonder, a cyanoacrylate ester (Henkel, Itapevi, Brazil), or a plug made with the root canal filling sealer prepared to a putty-like consistence.

The following experimental groups with 10 specimens per group were obtained: I - root canal filling with CRCS, without a plug; II - root canal filling with CRCS, with a CRCS plug; III - root canal filling with CRCS, with a plug of Coltosol; IV - root canal filling with CRCS, with a plug of Super Bonder; V - root canal filling with Endofill, without a plug; VI - root canal filling with Endofill, with a plug of Endofill; VII - root canal filling with Endofill, with a plug of Coltosol; VIII - root canal filling with Endofill with a plug of Super Bonder. Ten teeth with root canals not filled were taken as the positive control group and 10 other teeth with root canals filled and totally coated with Araldite were taken as the negative control group.

After filling, all specimens were immersed in saline for 24 hours. After this time, the teeth were immersed in a $2 \%$ methylene blue dye solution, with $\mathrm{pH} 7.0$, in a $0.002 \mathrm{mmHg}$ vacuum environment produced by an Arthur Pheipher pump (Wetzlar, Western Germany). After removing the air, the pieces remained in the methylene blue dye solution for 24 hours. The pieces were then washed in water, dried and sectioned longitudinally through the middle, after making a groove on the lingual and buccal aspects, without reaching the root canal. The teeth were then broken in half with a chisel. The linear leakages were evaluated with a micrometric ocular and a stereoscopic magnifying glass.

\section{RESULTS}

In the negative control group there was no leakage, whereas in the positive control group total leakage was observed. The means of the linear measurements of leakage in the different experimental groups are presented in Table 1. The data in Table 1 were compared statistically by ANOVA and the Kruskal-Wallis test, which showed significant differences at the $1 \%$ level between some experimental groups.

During analysis with the stereoscopic magnifying glass, methylene blue dye solution was found to penetrate the root canal filling not only through the interface filling materialdentin, but also through the interface gutta-percha pointsealer material, reaching dentin walls in depth. In the groups with Super Bonder there was $1 \mathrm{~mm}$ of a plug and a thin layer of the material in the dentin walls. In the experimental groups with Super Bonder plugs there was no leakage, except for one case in each group. The microscopic examination 
showed that, in these two cases, there were problems during Super Bonder application that left some holes in the plugs.

\section{DISCUSSION}

The most probable factor for the observed dye leakage would be the inadequate sealing promoted by the root canal filling materials. Nevertheless, when the root canal filling cement was employed as a plug over the root canal filling remainder, leakage decreased fairly well, mainly in the case of the sealer CRCS, whose plug was more effective than that of Endofill. The likely factor for leakage between guttapercha points and the sealer may be the adhesive property of the sealer. However, it seems that, when in contact with dentin walls, the adhesive property of the sealer was more efficient, as leakage was very small with the plug. It should be remembered that the powder-liquid ratio of the cement as root canal filling was different when employed as a plug. In the case of the plug, the cement was prepared with less liquid. Some in vitro experiments showed less leakage in root canals filled with cements prepared with less liquid ${ }^{9}$.

Valera and $\mathrm{Cia}^{17}$ filled root canals of extracted human teeth with gutta-percha points and zinc oxide-eugenol cement, making or not a 1-mm plug with the sealer employed for filling. They observed $1.30 \mathrm{~mm}$ of leakage in the group with zinc oxide eugenol plug. In the present research, the experimental group with a plug of the employed sealer displayed $0.11 \mathrm{~mm}$ of leakage for CRCS and $0.28 \mathrm{~mm}$ for Endofill (a Grossman cement). The main difference between the two researches was that Valera and $\mathrm{Cia}^{17}$ employed the plug sealer with the same ratio powder-liquid of the root canal filling, while in the present study the plug was made with a putty-like consistence, much more solid than the sealer employed for root canal filling.
In the present research, one of the liable factors for the observed leakage was probably the interface between guttapercha points and filling cement. It is possible that the employment of a gutta-percha condenser instrument would eliminate that interface by mixing gutta-percha with the sealer. Nevertheless, it is necessary to see if the heat delivered would also lead to contraction of the filling material. Some authors studied coronal and apical leakage after root canal filling by different techniques and reported different results according to the filling technique employed ${ }^{3,11}$.

Another detail to be considered is the result with the Super Bonder plug, which showed the best protection of the root canal filling. These results support the one reported in other investigation ${ }^{17}$. The problem of making that plug is the thin layer of the material that always remained on the walls of the canal, which is very difficult to remove, and any occurrences after cementation of the post are unknown.

In conclusion, leakage may occur not only between the filling material and the dentin walls, but also through the interface gutta-percha point-filling cement. The plugs influenced the results and the statistical analysis ordered the experimental groups from the best to the worst results in the following way: a - Endofill-Super Bonder, CRCS-Super Bonder, CRCS-CRCS; b- Endofill-Endofill; c - EndofillColtosol, CRCS-Coltosol; d-Endofill, CRCS.

TABLE 1- Averages of linear leakage observed in the different experimental groups

\begin{tabular}{|c|c|c|c|c|}
\hline $\begin{array}{l}\text { Experimental } \\
\text { Groups }\end{array}$ & $\begin{array}{l}\text { Number of } \\
\text { specimens }\end{array}$ & $\begin{array}{l}\text { Means* } \\
\text { of leakage } \\
(\mathrm{mm})\end{array}$ & $\begin{array}{l}\text { Linear } \\
\text { minimum }\end{array}$ & $\begin{array}{l}\text { Leakage }(\mathrm{mm}) \\
\text { maximum }\end{array}$ \\
\hline E.Fill - S.Bonder** & 10 & $0.03 \mathrm{a}$ & 0.00 & 0.77 \\
\hline CRCS - S.Bonder** & 10 & $0.05 \mathrm{a}$ & 0.00 & 1.11 \\
\hline CRCS - CRCS** & 10 & $0.11 \mathrm{a}$ & 0.00 & 1.11 \\
\hline E.Fill - E. Fill** & 10 & $0.28 \mathrm{~b}$ & 0.11 & 2.22 \\
\hline E.Fill - Coltosol** & 10 & $0.42 \mathrm{c}$ & 0.55 & 1.33 \\
\hline CRCS - Coltosol** & 10 & $0.55 \mathrm{c}$ & 0.77 & 2.33 \\
\hline E.Fill & 10 & $1.08 \mathrm{~d}$ & 1.11 & 3.33 \\
\hline CRCS & 10 & $1.43 \mathrm{~d}$ & 1.33 & 5.00 \\
\hline
\end{tabular}

*Means followed by the same letters do not differ statistically. There was a significant difference $(p<0.01)$ among the different letters.

** Plug material.

S.Bonder - Super Bonder; E. Fill - Endofill. 


\section{REFERENCES}

1- Abramovitz L, Lev R, Fuss Z, Metzger Z. The unpredictability of seal after post space preparation: a fluid transport study. J Endod $2001 ; 27: 292-5$

2- Barbosa HG, Holland R, Souza V, Dezan Junior E, Bernabé PFE, Otoboni Filho JA, Nery MJ. Healing process of dog teeth after postspace preparation and exposition of the filling material to the oral environment. Braz Dent J 2003; 14:103-8.

3- De Moor RJG, Hommez GMG. The long term sealing ability of an epoxy resin root canal sealer used with five gutta-percha obturation techniques. Int Endod J 2002; 35:275-82.

4- Holland R, Alexandre AC, Murata SS, Santos CA, Dezan Junior E. Apical leakage following root canal dressing with calcium hydroxide. Endod Dent Traumatol 1995; 11:261-3.

5- Holland R, Criveline MM, Zampieri Júnior M, Souza V, Saliba O. Qualidade do selamento marginal obtido com diferentes cimentos à base de hidróxido de cálcio. Rev Paul Odontol 1991; 13:27-35.

6- Holland R, Cruz A, Souza V, Nery MJ, Bernabé PFE, Otoboni Filho JA, Dezan Junior E. Comportamiento de los tejidos periapicales frente a la exposición de la obturación endodóntica al medio oral. Estudio histológico en dientes de perros. Endodoncia 2000; 18:99-108.

7- Holland R, Murata SS, Dezan Junior E, Garlipp O. Apical leakage after root canal filling with an experimental calcium hydroxide guttapercha point. J Endod 1996; 22:71-3.

8- Holland R, Sakashita MS, Murata SS, Dezan Junior E. Effect of dentine surface treatment on leakage of root fillings with a glass ionomer sealer. Int Endod J 1995; 28:190-3.

9- Holland R, Souza V, Abdalla T, Russo MC. Sealing properties of some root filling materials evaluated with radioisotope. Aust Dent J $1974 ; 19: 322-5$
10- Holland R, Souza V, Otoboni Filho JA, Nery MJ, Bernabé PFE, Mello W. Técnicas mistas de preparo do canal radicular. Rev Paul Odontol 1991; 13:17-23.

11- Jacobson HLJ, Xia T, Baumgartner JC, Marshall JG, Beeler WJ. Microbial leakage evaluation of the continuous wave of condensation. J Endod 2002; 28:269-71.

12- Metzger Z, Abramovitz R, Abramovitz L, Tagger M. Correlation between remaining length of root canal fillings after immediate postspace preparation and coronal leakage. J Endod 2000; 16:724-8.

13- Molven O, Halsen A. Success rates for gutta-percha and kloperka $\mathrm{N}-\varnothing$ root fillings made by undergraduate students: radiographic findings after 10-17 years. Int Endod J 1988; 21:243-50.

14- Porkaew P, Retief H, Barfield RD, Lacefield WR, Soong SJ. Effects of calcium hydroxide paste as an intracanal medicament on apical seal. J Endod 1990; 16:369-74.

15- Swanson K, Madison S. An evaluation of coronal microleakage in endodontically treated teeth. Part I. Times periods. J Endod 1987; 13:56-9.

16- Torabinejad M, Ung B, Kettering JD. In vivo bacterial penetration of coronally unsealed endodontically treated teeth. J Endod 1990; 16:566-9.

17- Valera MC, Cia D. Impermeabilização da obturação do canal radicular após preparo para núcleo. Rev Gauch Odontol 2000; 48:15760 .

18- Wu MK, Degee AJ, Wesslink PR, Moorer WR. Fluid transport and bacterial penetration along root canal. Int Endod J 1993; 26:2038 . 